\title{
Agronomic and Physiological Responses of Rice (Oryza sativa L.) under Different Water Management Systems, Fertilizer Types and Seedling Age
}

\author{
Kyi Mon Mon Ko ${ }^{1,2^{*}}$, Yasumaru Hirai' ${ }^{1}$, Oscar B. Zamora ${ }^{3}$, Lucille Elna de Guzman ${ }^{3}$ \\ ${ }^{1}$ Laboratory of Agricultural Machinery and Production Systems Design, Faculty of Agriculture, Kyushu University, \\ Fukuoka, Japan \\ ${ }^{2}$ Department of Agronomy, Yezin Agricultural University, Yezin, Myanmar \\ ${ }^{3}$ University of the Philippines Los Baños (UPLB), Los Baños, Philippines \\ Email: ^kyimonmonko.agro@gmail.com
}

How to cite this paper: Ko, K.M.M., Hirai, Y., Zamora, O.B. and de Guzman, L.E. (2017) Agronomic and Physiological Responses of Rice (Oryza sativa L.) under Different Water Management Systems, Fertilizer Types and Seedling Age. American Journal of Plant Sciences, 8, 3338-3349. https://doi.org/10.4236/ajps.2017.813225

Received: October 15, 2017

Accepted: December 12, 2017

Published: December 15, 2017

Copyright $\odot 2017$ by authors and Scientific Research Publishing Inc. This work is licensed under the Creative Commons Attribution International License (CC BY 4.0).

http://creativecommons.org/licenses/by/4.0/

(c) (i) Open Access

\begin{abstract}
A field experiment was conducted to evaluate the agronomic and physiological responses of rice under different water management systems, types of fertilizer and seedling age. This experiment was done at the farm of Agri Park, College of Agriculture, Central Experimental Station (CES), Crop Science Cluster of the University of the Philippines Los Baños, College Laguna during 2013. The strip-split plot design with three replications was used with the two types of fertilizer (vermicompost and chemical fertilizer), water management (with and without standing water) and two seedling ages (10 and 14-d old) were the treatments in the experiment. Chemical fertilizer produced the highest grain yield, total dry matter (TDM), leaf area index (LAI), net assimilation rate (NAR) and crop growth rate (CGR). Most of these characters significantly increased in 10-d old seedlings with chemical fertilizer without standing water. The shorter phyllochron and higher root pulling resistance (RPR) were observed in 10-d old seedlings without standing water. For the variety NSIC Rc 216, the use of 10-d old seedlings grown without standing water with chemical fertilizer is the optimum conditions for the better growth and high productivity.
\end{abstract}

\section{Keywords}

Phyllochron, Root Pulling Resistance (RPR), Total Dry Matter (TDM),

Leaf Area Index (LAI), Crop Growth Rate (CGR),

Net Assimilation Rate (NAR), Grain Yield 


\section{Introduction}

Rice acreage in Myanmar in 2008 is 8 million ha with an average grain yield of $3.72 \mathrm{t} \cdot \mathrm{ha}^{-1}$, which is much lower compared to potential yield of the newly developed varieties [1]. About $7 \%-10 \%$ of total rice growing area acreage is under submerged conditions for 2 - 10 days or even longer. Such conditions do considerable damage to the rice crop stand because delayed replanting does not favor optimum production [2]. According to [3], increasing $\mathrm{N}$ rates resulted in higher rice paddy yields in plots without standing water than with continuous standing water. Young seedlings below $10 \mathrm{~d}$ of age are transplanted in the system of rice intensification [4], which produce higher number of tillers than normal rice production systems and contribute to higher grain yields [5]. The same authors noted that rice seedlings transplanted before commencing the fourth phyllochron retained their higher tillering potential than that of seedlings more than 14-d old. [6] reported that 8 - 15-d old seedlings have performed better than transplanting 21 - 23-d old seedlings. [7] and [8] observed highest yields with 8 - 15 days old seedlings transplanted at 25 hills $\mathrm{m}^{-2}$ in Madagascar and with 10-d old seedlings in Sumatra. [9] observed high grain yields of $3.25 \mathrm{t} \cdot \mathrm{ha}^{-1}$ with 12 -d old seedlings than 8-, 16- and 25-d old seedlings and the yield decline of seedlings of latter three ages was primarily attributed to the reduction in the number of tillers. Organic fertilizers are natural materials of either plant or animal origin including livestock manure, green manure, crop residues, household waste, etc. Organic fertilizer is an effective agent for improving soil quality in the long term. Being from waste products, it reduces the cost of agricultural production [10]. Vermicomposting is the application of earthworm in producing vermifertilizer, which helps in the maintenance of better environment and results in sustainable agriculture [11]. [12] and [13] reported that increasing nitrogen levels up to 120 $\mathrm{kg} \cdot \mathrm{N} \cdot \mathrm{ha}^{-1}$ significantly increased plant height, leaf area, yield component and grain yield. Rice growth characteristics namely plant height, tillers $\mathrm{m}^{-2}$, leaf area index, dry matter content, grain yield and its components were significantly increased when rice was fertilized with $144 \mathrm{~kg} \cdot \mathrm{N} \cdot \mathrm{ha}^{-1}$ as double-split application (incorporated in dry soil: immediately before planting and the rest at panicle initiation). [14] found that maximum tillering, panicle initiation, heading date, crop growth rates, leaf area index and grain yield were increased by increased nitrogen levels of up to $165 \mathrm{~kg} \cdot \mathrm{N} \cdot \mathrm{ha}^{-1}$. This study was conducted to evaluate the effects of different seedling age at transplanting, two water management systems, and different fertilizer types for better growth and higher productivity of rice.

\section{Materials and Methods}

\subsection{Crop Management and Fertilizer Application}

The unit plot size was $6 \mathrm{~m} \times 5 \mathrm{~m}$ that were separated by $0.5 \mathrm{~m}$ dikes. One meter canals were placed between the water treatments (with and without standing water). The total experimental size was $730 \mathrm{~m}^{2}$. The dikes were constructed between each plot, while canals for irrigation and drainage were dug around the 
experimental field. The seedlings were established on fertile soil media in plastic trays. The seeds were soaked in clean water for $12 \mathrm{hs}$ then incubated under warm and moist conditions for $24 \mathrm{hs}$ and then seeds were covered with a fine layer of soil. The seeded plastic trays were watered as necessary. The seedlings were transplanted at 10-d old with 2 seedlings per hill and 14-d old with 2 seedlings per hill at $20 \times 20 \mathrm{~cm}$ spacing. Missing hills were replanted 3 days after transplanting (DAT).

For organic fertilizer treatment, only vermicompost $\left(1.92 \% \mathrm{~N}, 0.60 \mathrm{ppm} \mathrm{P}_{2} \mathrm{O}_{5}\right.$ and $0.51 \mathrm{me} / 100 \mathrm{~g}$ soil $\left.\mathrm{K}_{2} \mathrm{O}\right)$ was applied at $6 \mathrm{~kg}$ per plot $\left(2 \mathrm{t} \cdot \mathrm{ha}^{-1}\right)$. There were 2 applications; the first time was after the last harrowing and the last time was at 14 DAT. The chemical fertilizers (14-14-14) were applied at $90 \mathrm{~kg} \mathrm{~N}, 60 \mathrm{~kg} \mathrm{P}_{2} \mathrm{O}_{5}$, and $60 \mathrm{~kg} \mathrm{~K}_{2} \mathrm{O} \mathrm{ha}{ }^{-1}$. An additional $30 \mathrm{~kg}$ of urea was applied for the remaining $60 \mathrm{~kg} \mathrm{~N}$. Half of the fertilizers (N P K and urea) and were applied at 14 DAT and the second half were used at $30 \mathrm{DAT}$.

For inorganic treatments, Cymbush insecticides were applied at 10, 15, 20, 20 $\mathrm{mL}$ mixed with $16 \mathrm{~L}$ water at the vegetative stage, booting stage, $50 \%$ flowering stage and $80 \%$ flowering stage, respectively. At the same time, a mixture of $150 \mathrm{~g}$ of ground chili and $16 \mathrm{~L}$ water was applied to the organic treatments. There was no disease observed. Zinc phosphide (rodenticide) was also applied to protect from rat damage. Hand weeding was done at weekly intervals from one week after transplanting (WAT) until maturity.

\subsection{Soil Sampling and Analysis}

A composite soil sample was collected from experimental field before the start and after experiment. Soil samples were collected in zigzag manner using an auger for digging to a depth of $20 \mathrm{~cm}$ before the start of the experiment. Soil samples were analyzed at Soil Science Laboratory, Agricultural Systems Cluster at UPLB before rice sowing. Soil analyses were performed to determine total $\mathrm{N}$, available $\mathrm{P}$, exchangeable $\mathrm{K}$, organic matter content and soil $\mathrm{pH}$ (Table 1).

\subsection{Vermicompost Analysis}

Vermicompost was analyzed at Soil Science Laboratory, Agricultural Systems

Table 1. Chemical properties of the soil before and after experiment.

\begin{tabular}{ccccc}
\hline \multirow{2}{*}{$\begin{array}{c}\text { CHEMICAL PROPERTIES } \\
\text { pH }\end{array}$} & \multicolumn{2}{c}{ ORGANIC SOIL } & \multicolumn{2}{c}{ INORGANIC SOIL } \\
\cline { 2 - 5 } Organic Matter (\%) & 6.1 & 6.5 & 5.8 & 6.4 \\
Total N (\%) & 2.99 & 4.74 & 2.99 & 4.66 \\
Available P (ppm) & 0.15 & 0.2 & 0.18 & 0.23 \\
Exchangeable K (me/100g soil) & 15 & 30 & 12 & 47 \\
\hline
\end{tabular}

Results analyzed by Soil Laboratory, Agricultural Systems Cluster, UPLB. 
Cluster at UPLB to determine the composition of total $\mathrm{N}, \mathrm{P}_{2} \mathrm{O}_{5}$, and $\mathrm{K}_{2} \mathrm{O}(1.92 \%$ $\mathrm{N}, 0.60$ ppm $\mathrm{P}_{2} \mathrm{O}_{5}$ and $0.51 \mathrm{me} / 100 \mathrm{~g}$ soil $\mathrm{K}_{2} \mathrm{O}$ ) before rice sowing.

\subsection{Phyllochron Index (Leaf Number)}

Five sample plants were randomly selected from center rows of each plot. The stage of leaf development (Haun leaf number), the phyllochron of each leaf, and the total number of leaves on the main culm were measured every 3 DAT up to the complete exertion of the flag leaf. Haun leaf number was calculated according to the following formula.

$$
\text { Haun leaf }=\left(L_{n} / L_{n-1}\right)+(n-1) \quad[15]
$$

where: $L_{n}=$ the length of the youngest leaf blade above the collar of subtending leaf, $L_{n-1}=$ the length of the blade of the penultimate (subtending) leaf, $n=$ the total number of leaves that are visible on the main culm.

\subsection{Phyllochron Measurement}

The phyllochron $\left(\mathrm{d} \cdot \mathrm{leaf}^{-1}\right)$ on the main culm of each sample plants were measured using the following formula of [16].

Phyllochron $\left(\mathrm{d} \cdot\right.$ leaf $\left.^{-1}\right)=$ Number of elapsed $\mathrm{d}$ between the two consecutive Haun leaves/measurement difference between the two consecutive Haun leaf number measurements.

\subsection{Root Pulling Resistance (RPR)}

This was measured using a $100 \mathrm{~kg}$ spring balance to estimate the root strength [17]. The plant was tied up at the base with plastic string and pulled out with attached spring balance to obtain RPR in $\mathrm{kg}$. The measurements were done four times starting at $44 \mathrm{DAT}$ at weekly interval. The weights of the roots adhering to the pulled plants were recorded.

\subsection{Growth Parameters}

Leaf Area Index (LAI), Total Dry Matter (TDM), Crop Growth Rate (CGR) and Net Assimilation Rate (NAR) were determined by cutting plant parts separately from the three sample plants of destructive area and oven-dried at biweekly intervals starting from 30 DAT until maturity by using the following formula:

$$
\begin{gathered}
\mathrm{LAI}=\text { Leaf area }(\mathrm{LA})\left(\mathrm{cm}^{2}\right) / \operatorname{Ground} \operatorname{area}(\mathrm{GA}) \quad \text { [18] } \\
\qquad \mathrm{CGR}=W_{2}-W_{1} / T_{2}-T_{1} \text { [19] }
\end{gathered}
$$

where: $W_{2}=$ plant dry weight at time $T_{2}$ and $W_{1}=$ plant dry weight at time $T_{1}, T_{1}$ = Time unit at first harvest, $T_{2}=$ Time unit at next harvest.

$$
\mathrm{NAR}=\left(W_{2}-W_{1}\right)\left(\ln L A_{2}-\ln L A_{1}\right) /\left(L A_{2}-L A_{1}\right)\left(T_{2}-T_{1}\right)
$$

where: $W_{2}=$ plant dry weight at time $T_{2}, \mathrm{~W}_{1}=$ plant dry weight at time $T_{1}, L A_{2}=$ leaf area at time $T_{2}, L A_{1}=$ leaf area at time $T_{1}$, $\ln =$ base of natural logarithm, $T_{1}=$ Time unit at first harvest, $T_{2}=$ Time unit at next harvest. 


\subsection{Yield and Yield Components}

It was computed from $1 \mathrm{~m}^{2}$ harvest area at the inner rows, excluding a border row along the four sides of each plot. The grains, panicles, spikelets from each plot were weighed and moisture content was determined. Grain yields were adjusted at $14 \%$ moisture by using the following formula and expressed as tha ${ }^{-1}$.

$$
\begin{gathered}
A \times W \\
A=(100-M C \%) / 86 \quad[18]
\end{gathered}
$$

where: $A=$ Adjustment coefficient, $W=$ Weight of harvested grains, $M C=$ moisture content.

\subsection{Data Analysis}

All data were analyzed using the Statistical Analysis System (SAS version 6.12). Treatment means comparisons were carried out using Least Significance Difference (LSD) at $5 \%$ level of significance [20].

\section{Results and Discussion}

\subsection{Phyllochron (d·leaf-1)}

The phyllochron of each leaf on the main culm of rice as affected by water management and seedling age was shown in (Table 2). In this table, the 10-d old seedling was found the longer phyllochron ( $>5$ days) at leaf number four at both water conditions and shorter starting at leaf number five to 12. A similar trend was also observed in 14-d old seedling. Shorter phyllochron ( $<5$ days) were observed from leaf number three to 12 . The longer phyllochrons $(>7)$ were observed in the later leaf appearances. The phyllochron with inorganic treatment was slightly longer than with organic fertilizer. However, the differences were not significantly different. Water stress appears to have an impact on phyllochron, but only at extreme stress [21] [22]. [9] found that rice plants experience

Table 2. The phyllochron of each leaf (after transplanting) as affected by water manage-

\begin{tabular}{|c|c|c|c|c|c|c|c|c|c|c|c|c|c|c|c|c|c|c|c|}
\hline \multirow{2}{*}{$\begin{array}{c}\text { Water } \\
\text { Management }\end{array}$} & \multicolumn{19}{|c|}{ LEAF NUMBER ON THE MAIN CULM } \\
\hline & 1 & 2 & 3 & 4 & 5 & 6 & 7 & 8 & 9 & 10 & 11 & 12 & 13 & 14 & 15 & 16 & 17 & 18 & $\begin{array}{c}\text { Total number } \\
\text { of leaves }\end{array}$ \\
\hline \multicolumn{20}{|c|}{$10-\mathrm{d}$ old } \\
\hline $\begin{array}{c}\text { With } \\
\text { standing water }\end{array}$ & - & - & 3 & 6 & 4 & 4 & 3 & 3 & 4 & 4 & 5 & 4 & 6 & 7 & 7 & 7 & 7 & - & 15 \\
\hline $\begin{array}{c}\text { Without } \\
\text { standing water }\end{array}$ & - & - & 4 & 6 & 4 & 4 & 4 & 3 & 4 & 5 & 5 & 5 & 5 & 7 & 7 & 7 & 7 & - & 15 \\
\hline \multicolumn{20}{|c|}{ 14-d old } \\
\hline $\begin{array}{c}\text { With } \\
\text { standing water }\end{array}$ & - & - & 3 & 5 & 4 & 4 & 4 & 3 & 3 & 5 & 5 & 5 & 6 & 7 & 7 & 7 & 7 & - & 15 \\
\hline $\begin{array}{c}\text { Without } \\
\text { standing water }\end{array}$ & - & - & 4 & 5 & 4 & 4 & 4 & 3 & 4 & 5 & 5 & 5 & 5 & 7 & 7 & 7 & 7 & - & 15 \\
\hline
\end{tabular}
ment and seedling age. 
shorter phyllochrons when seedlings of less than $12 \mathrm{~d}$ are transplanted at two leaf stage. The younger seedlings have shorter phyllochron than older seedlings [23].

\subsection{Root Pulling Resistance (RPR) (kg·plant $\left.{ }^{-1}\right)$}

Younger (10-d old) seedlings at transplanting had significantly higher RPR than older seedling across water management in (Table 3). The 10-d old seedling has significantly the highest RPR without standing water and this was significantly higher than the RPR of the 14-d old seedling without standing water. [24] reported that for SRI plants with single plant hill ${ }^{-1}$, the mean RPR was 49.67 to $55.19 \mathrm{~kg}$. However, in this study, the values attained were lower than that reported by [24] at $26.25-32.78 \mathrm{~kg}$. Some reasons for those are the narrower spacing $(20 \mathrm{~cm} \times 20 \mathrm{~cm})$ and the use of $2-3$ seedlings hill ${ }^{-1}$ while [24] used wider spacing $(30 \mathrm{~cm} \times 30 \mathrm{~cm})$ and single seedling hill ${ }^{-1}$. Under SRI conditions, using young seedling, widely spaced, one per hill, no standing water recorded 53 $\mathrm{kg}$ of pulling force [25]. Root biomass or root length was measured in the present experiment but it appears that the presence of standing water has resulted to reduced root biomass and/or root length and hence, less anchorage.

\subsection{Total Dry Matter (TDM) $\left(\mathrm{g} \cdot \mathrm{m}^{-2}\right)$}

Total dry matter increased with time with the highest value recorded for plants with chemical fertilizer at 72 DAT (Table 4). At 72 DAT, the highest total dry matter was recorded for chemical fertilizer without standing water, followed by chemical fertilizer with standing water, and the lowest was with organic fertilizer without standing water. There was no significant difference in total dry matter due to water management and the interaction between fertilizer type and seedling age. [4] reported that the rice plants produce increased plant dry weight with no standing water condition at near maturity. Positive influence of phosphorus on total dry matter in rice was also reported by [26] and [27]. The younger seedlings applied with nitrogen fertilizer and limited irrigation helped in improving new roots, better root growth and more tiller production resulting in an improvement with higher total dry matter [18] [28].

\subsection{Leaf Area Index (LAI)}

LAI increased with time up to 58 DAT for both organic and inorganic treatments and then declined thereafter up to 72 DAT (Figure 1). LAI of plants with

Table 3. Root pulling resistance $\left(\mathrm{kg} \mathrm{plant}^{-1}\right)$ as affected by the interaction between water management and seedling age at $51 \mathrm{DAT}$.

\begin{tabular}{cccc}
\hline \multirow{2}{*}{ Seedling age } & \multicolumn{3}{c}{ Water management } \\
\cline { 2 - 4 } & With standing water & Without standing water & Mean \\
\hline 10-d old & $29.28 \mathrm{ab}$ & $32.78 \mathrm{a}$ & $31.03 \mathrm{a}$ \\
14-d old & $31.33 \mathrm{ab}$ & $26.25 \mathrm{~b}$ & $28.79 \mathrm{~b}$ \\
Mean & $30.31 \mathrm{ab}$ & $29.52 \mathrm{~b}$ & \\
\hline
\end{tabular}




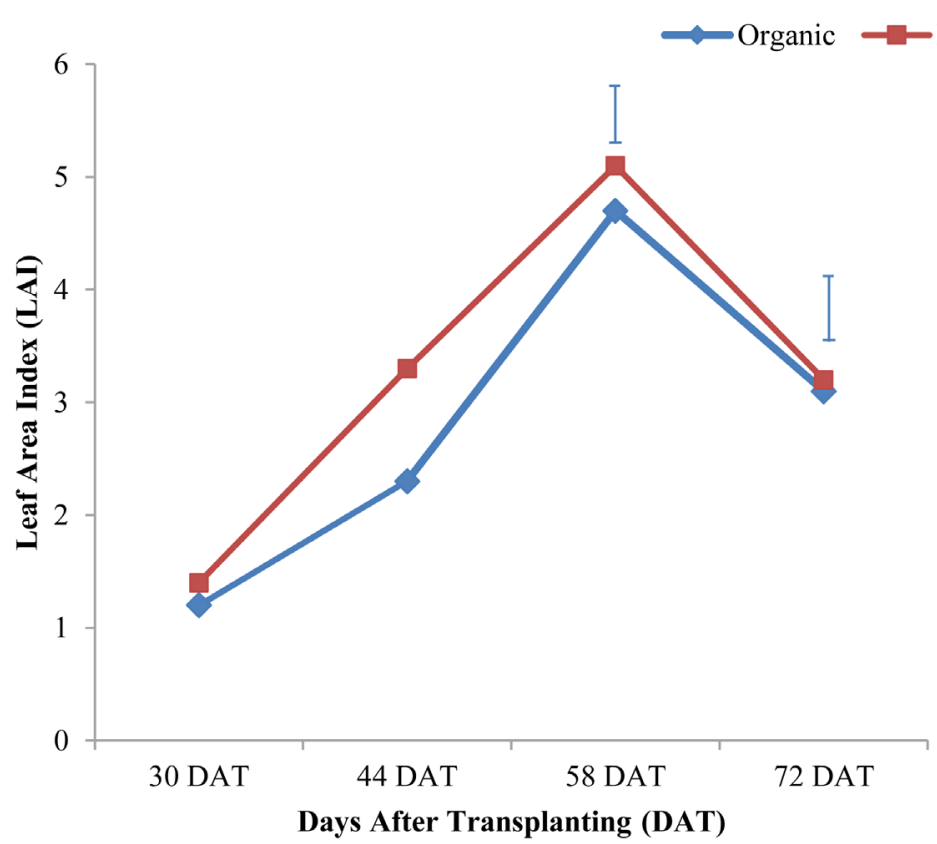

Figure 1. Change with time in leaf area index as affected by fertilizer type at different growth stages. Vertical bars show LSD $(p=0.05)$.

Table 4. Total dry matter $\left(\mathrm{g} \cdot \mathrm{m}^{-2}\right)$ as affected by fertilizer and water management at 72 DAT.

\begin{tabular}{ccc}
\hline \multirow{2}{*}{ Fertilizer type } & \multicolumn{2}{c}{ Water management } \\
\cline { 2 - 3 } & With standing water & Without standing water \\
\hline Organic & $114.24 \mathrm{c}$ & $88.77 \mathrm{~d}$ \\
Inorganic & $142.90 \mathrm{~b}$ & $169.30 \mathrm{a}$ \\
\hline
\end{tabular}

chemical fertilizer were significantly higher than those with organic fertilizers. The highest LAI was obtained from 10-d old seedling with chemical fertilizer type (Table 5). [12] reported that nitrogen fertilizer influence LAI by increasing tiller number and size of leaves. [29] found that young seedlings, closer spacing and urea application recorded more tillers per unit area resulting to increased LAI. LAI was highly significant affected by fertilizer type at all growth stages.

\subsection{Crop Growth Rate (CGR) (g.m-2.d-1)}

There was similar pattern of CGR with time in both fertilizer types, i.e., the maximum value was attained between $44 \mathrm{DAT}$ and $58 \mathrm{DAT}$ (Figure 2). The higher CGR at this stage was due to higher number of leaves and onset of panicle initiation. After this stage, CGR value declined sharply at $58-72 \mathrm{DAT}$, and this was attributed to leaf senescence. The result was similar to earlier reports by [30] and [31]. Increased LAI and total dry matter production using younger seedlings and without standing water have resulted to higher CGR [32]. [33] stated that during initial growth stage, CGR and NAR values increased due to more number of tillers and leaves per unit area. 


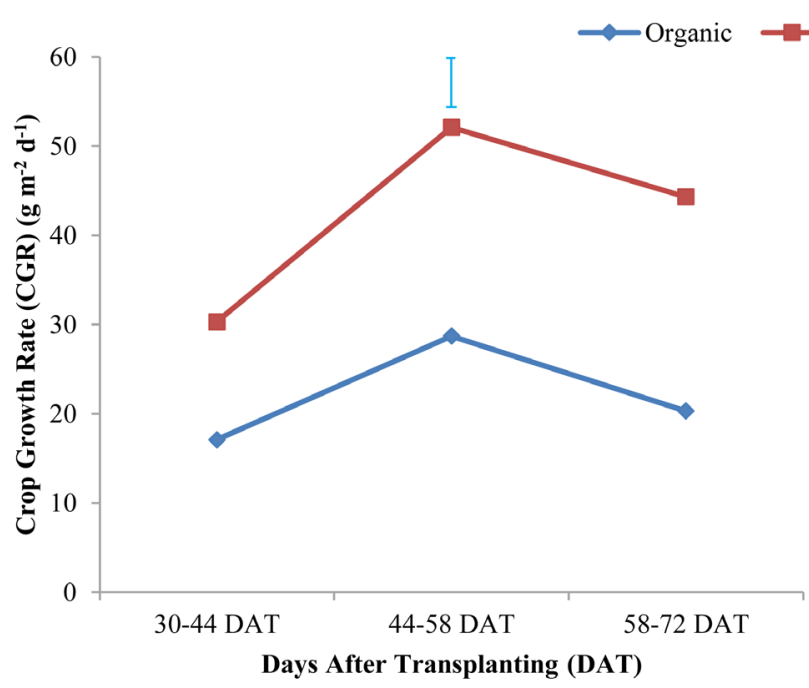

Figure 2. Change with time in crop growth rate using organic and chemical fertilizer. Vertical bar shows LSD $(p=0.05)$.

Table 5. Leaf area index as affected by fertilizer and seedling age interaction at $30 \mathrm{DAT}$.

\begin{tabular}{|c|c|c|c|}
\hline \multirow{2}{*}{ Seedling age } & \multicolumn{2}{|c|}{ Fertilizer } & \multirow{2}{*}{ Mean } \\
\hline & Organic & Inorganic & \\
\hline 10-d old & $1.4 \mathrm{c}$ & $3.1 \mathrm{a}$ & $2.3 \mathrm{a}$ \\
\hline 14-d old & $1.2 \mathrm{~d}$ & $2.7 \mathrm{~b}$ & $2.0 \mathrm{~b}$ \\
\hline MEAN & $1.3 \mathrm{~b}$ & $2.9 \mathrm{a}$ & \\
\hline
\end{tabular}

It was earlier reported by various authors [34] [35] [36] that maximum CGR of young seedlings at $25 \mathrm{~cm} \times 25 \mathrm{~cm}$ spacing was $30-50 \mathrm{~g} \cdot \mathrm{m}^{-2} \cdot \mathrm{d}^{-1}$ at $50-75$ DAT. However, during initial growth stages, closer spacing recorded higher CGR and NAR due to more number of tillers and leaves per unit area. Subsequently, increased total dry matter and limited irrigation increased growth [33] [37].

There was highly significant difference among fertilizer, water management, seedling age interaction at $44-58 \mathrm{DAT}$. The highest CGR value was observed for 14-d old seedling with chemical fertilizer without standing water at 44 - 58 DAT which were significantly higher than the CGR values of organic fertilizer at both seedling age and at both water managements (Table 6).

\subsection{Net Assimilation Rate (NAR) $\left(\mathrm{g} \cdot \mathrm{m}^{-2} \cdot \mathrm{d}^{-1}\right)$}

The highest NAR value was observed for 14-d old seedling with chemical fertilizer without standing water and this was significantly higher than the NAR values of organic fertilizer at 10-d old seedlings at both water managements and 14-d old seedlings without standing water; which in turn was not significantly different with the other treatments (Table 7). Higher NAR values of $6-8$ $\mathrm{g} \cdot \mathrm{m}^{-2} \cdot \mathrm{d}^{-1}$ for $14-\mathrm{d}$ old rice seedlings were reported with $25 \mathrm{~cm} \times 25 \mathrm{~cm}$ spacing at 45 DAT [35] [38]. In this experiment, slightly higher values $\left(9.33-11.12 \mathrm{~g} \cdot \mathrm{m}^{-2} \cdot \mathrm{d}^{-1}\right)$ were recorded with chemical fertilizer and without standing water. 
Table 6. Crop growth rate $\left(\mathrm{g} \cdot \mathrm{m}^{-2} \cdot \mathrm{d}^{-1}\right)$ as affected by the interaction among fertilizer type, water management and seedling age at $44-58$ DAT.

\begin{tabular}{ccccc}
\hline \multirow{2}{*}{ Fertilizer type } & \multicolumn{2}{c}{ With standing water } & \multicolumn{2}{c}{ Without standing water } \\
\cline { 2 - 5 } & $10-\mathrm{d}$ & $14-\mathrm{d}$ & $10-\mathrm{d}$ & $14-\mathrm{d}$ \\
\hline Organic & $28.4 \mathrm{~b}$ & $28.5 \mathrm{~b}$ & $30.6 \mathrm{~b}$ & $28.7 \mathrm{~b}$ \\
Inorganic & $51.5 \mathrm{a}$ & $50.3 \mathrm{a}$ & $50.7 \mathrm{a}$ & $52.1 \mathrm{a}$ \\
\hline
\end{tabular}

Table 7. Net assimilation rate $\left(\mathrm{g} \cdot \mathrm{m}^{-2} \cdot \mathrm{d}^{-1}\right)$ as affected by fertilizer, water management and seedling age at $44-58$ days after transplanting.

\begin{tabular}{ccccc}
\hline \multirow{2}{*}{ Fertilizer type } & \multicolumn{2}{c}{ With standing water } & \multicolumn{2}{c}{ Without standing water } \\
\cline { 2 - 5 } & $10-\mathrm{d}$ & $14-\mathrm{d}$ & $10-\mathrm{d}$ & $14-\mathrm{d}$ \\
\hline Organic & $3.44 \mathrm{~b}$ & $7.48 \mathrm{a}$ & $4.06 \mathrm{~b}$ & $4.26 \mathrm{~b}$ \\
Inorganic & $6.73 \mathrm{a}$ & $5.38 \mathrm{ab}$ & $9.33 \mathrm{a}$ & $11.12 \mathrm{a}$ \\
\hline
\end{tabular}

\subsection{Grain Yield (t·ha-1)}

The application of organic $\mathrm{N}$ using vermicompost, fertilizer $\mathrm{N}$ and bio fertilizer enhanced plant growth parameters, yield and yield components of rice [39]. The highest grain yield of $7.44 \mathrm{t} \cdot \mathrm{ha}^{-1}$, which was significantly higher than all other treatments, was recorded for the chemical treatment without standing water (Table 8). The highest grain yield was attained from plots without standing water. In SRI, the soil that is kept in moist condition produces more growth and grain yield of rice [8].

\section{Conclusion}

The highest TDM was recorded from chemical fertilizer without standing water at 72 DAT which was significantly higher than others. RPR was highly significantly affected by water management at 72 DAT. RPR at 51 DAT was significantly affected by fertilizer and seedling age interaction. In 10-d old seedling, the longer phyllochron ( $\geq 5$ days) was found at leaf number four at both water conditions and was shorter starting at leaf number 5 to 12 . LAI increased with time up to 58 DAT for both organic and chemical fertilizers and then it declined at 72 DAT. The highest LAI was obtained from 10-d old seedling with chemical fertilizer. The NAR of 14-d old seedling with chemical fertilizer without standing water was significantly higher than the NAR values of organic fertilizer at 10-d old seedlings at both water managements. There was similar pattern of CGR with time, i.e., the maximum value was attained between 44 DAT and 58 DAT and the similar trend was also observed with NAR. The highest grain yield was attained without standing water. The results of this experiment showed that the 10-d old seedlings without standing water gave better plant growth than 14-d old seedlings. Moreover, chemical fertilizer has significant effect on the agronomic and physiological parameters in comparison with vermicompost. Thus, the use of 10-d old seedlings grown without standing water with chemical fertilizer is the optimum conditions for the better growth and high productivity of NSIC Rc 216 (Tubigan 17). 
Table 8. Grain yield $\left(\mathrm{t} \cdot \mathrm{ha}^{-1}\right)$ as affected by the interaction between fertilizer type and water management at harvest.

\begin{tabular}{ccc}
\hline \multirow{2}{*}{ Fertilizer type } & \multicolumn{2}{c}{ Water management } \\
\cline { 2 - 3 } & With standing water & Without standing water \\
\hline Organic & $4.58 \mathrm{c}$ & $3.75 \mathrm{~d}$ \\
Inorganic & $5.86 \mathrm{~b}$ & $7.44 \mathrm{a}$ \\
\hline
\end{tabular}

\section{Acknowledgements}

This work was supported by Ministry of Education, Culture, Sports, Sciences and Technology of Japan (MEXT). I would like to extend sincere gratitude to the Southeast Asian Regional Center for Graduate Study and Research in Agriculture (SEARCA) for their financial support.

\section{References}

[1] International Rice Research Institute (2012) Rice Fact Sheets of Myanmar. Los Baños, Philippines. http://ricepedia.org/myanmar

[2] Kamoshita, A., Wade, L.J. and Yamauchi, A. (2000) Genotypic Variation in Response of Rainfed Lowland Rice to Drought and Rewatering. III. Water Extraction during the Drought Period. Plant Production Science, 3, 189-196.

https://doi.org/10.1626/pps.3.189

[3] Turner, B.L. and Haygarth, P.M. (2001) Phosphorus Solubilization in Rewetted Soils. Nature, 411, 258. https://doi.org/10.1038/35077146

[4] Stoop, W.A., Uphoff, N. and Kassam, A. (2002) A Review of Agricultural Research Issues Raised by the System of Rice Intensification (SRI) From Madagascar: Opportunities for Improving Farming Systems for Resource Poor Farmers. Agricultural Systems, 71, 249-274. https://doi.org/10.1016/S0308-521X(01)00070-1

[5] Krishna, A., Biradapatil, N.K., Manjappa, K. and Channappagoudar, B.B. (2008) Evaluation of System of Rice Intensification Cultivation, Seedling Age and Spacing on Seed Yield and Quality in Samba Masuhri (Bpt-5204) Rice. Karnataka. Journal of Agricultural Science, 21, 20-25.

[6] Makarim, A.K., Balasubramanian, V., Zaini, Z., Syamsiah, I. and Handoko, D. (2002) Systems of Rice Intensification (SRI): Evaluation of Seedling Age and Selected Components in Indonesia. In: Bouman, B.A.M., Hengsdijk, A., Hardy, B., Bindraban, P.S., Tuong, T.P. and Ladha, J.K., Eds., Water-Wise Rice Production, IRRI, Philippines, 129-139.

[7] McHugh, O.V., Steenhuis, T.S., Barison, J., Fernandes, E.C.M. and Uphoff, N.T. (2002) Farmer Implementation of Alternate Wet-Dry and Non-flooded Irrigation Practices in The System of Rice Intensification (SRI). In: Evaluation of Seedling Age and Selected Components in Indonesia. In: Bouman, B.A.M., Hengsdijk, A., Hardy, B., Bindraban, P.S., Tuong, T.P. and Ladha, J.K., Eds., Water-Wise Rice Production, IRRI, Philippines, 89-103.

[8] Thiyagarajan, T.M., Velu, V., Ramasamy, S., Durgadevi, D., Govindaranjan, K. and Pryadarshini, R. (2002) Effects of SRI Practices on Hybrid Rice Performance in Tamil Nadu, India. In. Bouman, B.A.M., Hardy, B., Bindraban, P.S., Toung, T.P. and Ladha, J.K., Eds., Water-Wise Rice Production, IRRI, Philippines, 119-129.

[9] Krishna, A. and Biradarpatil, N.K. (2009) Influence of Seedling Age and Spacing on 
Seed Yield and Quality of Short Duration Rice under System of Rice Intensification Cultivation. Karnataka. Journal of Agricultural Science, 22, 53-55.

[10] Havlin, J.L., Beaton, J.D., Tisdale, S.L. and Nelson, W.L. (2005) Soil Fertility and Nutrient Management. 7th Edition. Pearson Prentice Hall, Upper Saddle River, NJ, 460-481.

[11] Senapati, B.K. (1996) Organic Farming for Sustainable Agriculture. Proceedings and Recommendations, National Workshop on Organic Farming for Sustainable Agriculture, 2-5 December 1996, India, 187-189.

[12] Kumar, G.S., Reddy, S.N. and Ikramullah, M. (1995) Effect of Seedling Age and Nitrogen Level on Performance of Rice (Oryza sativa) under Late Planting. Indian Journal of Agricultural Science, 65, 354-355.

[13] Maske, N.S., Borkar, S.L. and Rujgire, H.J. (1997) Effect of Nitrogen Levels on Growth, Yield and Grain Quality of Rice. Journal of Soils and Crops, 2, 83-86.

[14] Abou-Khalifa, A.A. (2007). Performance of Two Hybrid Rice and Sakha 101 Rice Cultivars to Three Nitrogen Levels and Three Sowing Dates. Egypt. Journal of Plant Breeding, 11, 681-691.

[15] Haun, J.R. (1973) Visual Quantification of Wheat Development. Agronomy Journal, 65, 116-117. https://doi.org/10.2134/agronj1973.00021962006500010035x

[16] Wilhelm, W.W. and Mcmaster, G.S. (1995) Importance of the Phyllochron in the Studying Development and Growth of Grasses. In: Symposium on the Phyllochron, University of Nebraska, Lincoln, 120. https://doi.org/10.2135/cropsci1995.0011183X003500010001x

[17] O'toole, J.C. and Soemartono, N. (1981) Evaluation of a Simple Technique for Characterizing Rice Root Systems in Relation to Drought Resistance. Euphytica, 30, 283-290. https://doi.org/10.1007/BF00033989

[18] Yoshida, S. (1981) Fundamentals of Rice Crop Science. International Rice Research Institute, Los Baños, 296.

[19] Gardner, F.P., Pearce, R.B. and Mitchell, R.L. (1985) Physiology of Crop Plants. Iowa State University, Ames, 31-36.

[20] Gomez, K.A. and Gomez, A.A. (1984) Statistical Procedure for Agricultural Research. 2nd Edition, John Wiley and Sons Inc., New York.

[21] Bauer, A.A., Frank, B. and Black, A.L. (1984) Estimation of Spring Wheat Leaf Growth Rates and Anthesis from Air Temperature. Agronomy Journal, 76, 829-835. https://doi.org/10.2134/agronj1984.00021962007600050027x

[22] Baker, J.T., Pinter, P.T., Reginato, R.J. and Kanemasu, E.T. (1986) Effects of Temperature on Leaf Appearance in Spring and Winter Wheat Cultivars. Agronomy Journal, 78, 505-613. https://doi.org/10.2134/agronj1986.00021962007800040010x

[23] Uphoff, N. (2000) The System of Rice Intensification Developed in Madagascar. Conference on Raising Agricultural Productivity in the Tropics: Biophysical Challenges for Technology and Policy, Cambridge, 16-17 October 2000, 23-39.

[24] Barison, J. (2003) Nutrient-Use Efficiency and Nutrient Uptake in Conventional and Intensive (SRI) Rice Cultivation Systems in Madagasca. Master's Thesis, Department of Crop and Soil Sciences, Cornell University, Ithaca, 101.

[25] Uphoff, N., Kassam, A. and Stoop, W. (2008) A Critical Assessment of A Desk Study Comparing Crop Production Systems: The Example of the "System of Rice Intensification" versus "Best Management Practice". Field Crops Research, 108, 109-114. https://doi.org/10.1016/j.fcr.2007.12.016 
[26] Gupta, M.L. and Bhandra, D. (1980) Manganese Phosphate Relationship in Rice in Alluvial Soil. Journal of Indian Society of Soil Science, 28, 485-490.

[27] Sarkar, A.K. and Choudhary, K. (1988) Relative Efficiency of Different Methods of Phosphoric Fertilizer Application on Yield and P Nutrition of Rice. Indian Journal of Society of Soil Science, 36, 466-470.

[28] Rao, C.P. and Raju, M.S. (1987) Effect of Age of Seedlings, Nitrogen and Spacing on Rice. Indian Journal of Agronomy, 32, 100-102.

[29] Esther, S.D. (1996) Studies on the Optimization of Nursery Method, Seedling Age and Plant Density for Broadcast Planted Rice. M.Sc. Thesis, Tamil Nadu Agricultural University, Coimbatore, 92.

[30] Awal, M.A. and Khan, M.A.H. (2000) Mulch Induced Eco-Physiological Growth and Yield of Maize. Pakistan Journal of Biological Sciences, 3, 61-64. https://doi.org/10.3923/pjbs.2000.61.64

[31] Valero, A., De Juan, Maturano, M., Ramírez, A.A., Tarjuelo, J.M., Martín-Benito and Ortega Álvarez, J.F. (2005) Growth and Nitrogen Use Efficiency of Irrigated Maize in a Semiarid Region as Affected By Nitrogen Fertilization. Spanish Journal of Agricultural Research, 3, 134-144. https://doi.org/10.5424/sjar/2005031-133

[32] Rao, C.P., Rao, M.H., Krishnan, T.K. and Rana, B.S. (1998) Characterization of Sorghum Hybrids and Varieties for Growth Parameters, Biomass Accumulation and Yield Potential in Rainy Season. Indian Journal of Plant Physiology, 3, 269-273.

[33] Balasubramanian, R. (1998) Studies on Irrigation Requirement for Direct Seeded Rice. M.Sc. (Ag) Thesis, Tamil Nadu Agricultural University, Coimbatore, 72-86.

[34] Main, M.A. (2006) Influence of Planting Technique on Growth and Yield of Aman Rice. Master Thesis, Dept. of Agronomy, Sher-E-Bangla Agricultural University, Dhaka, 122.

[35] Vijayakumar, M., Ramesh, S., Prabhakaran, N.K., Subbian, P. and Chandrasekaran, B. (2006) Influence of System of Rice Intensification (SRI) Practices on Growth Characters, Days To Flowering, Growth Analysis and Labour Productivity of Rice. Asian Journal of Plant Sciences, 5, 984-989. https://doi.org/10.3923/ajps.2006.984.989

[36] Alma, M.M., Hasanuzzaman, M. and Nahar, K. (2009) Growth Pattern of Three High Yielding Rice Varieties under Different Phosphorus Levels. Advances in Biological Research, 3, 110-116.

[37] Ghildyal, B.P. and Tomar, V.S. (1982) Soil Physical Properties under Drought. In: Drought Resistance in Crops with Emphasis on Rice, IRRI, Los Baños, 83-96.

[38] Mohammad, S.B., Inayat, U.A. and Hassan, G. (2006) Growth and Yield of Rice as Affected by Transplanting Dates and Seedlings per Hill Under High Temperature of Dera Ismail Khan. Agronomy Journal, 7, 572-579.

[39] Jayabal, A. and Kuppuswamy, G. (1997) Food Security in Harmony with Nature. 3 rd Ifoam-Asia Scientific Conference and General Assembly, 61. 